\title{
A New Insight into Human Resource Management in College Library Based on Knowledge Management
}

\author{
Qin Qiang ${ }^{1,}$, \\ ${ }^{1}$ Hebei Agricultural University Library, Baoding City, Hebei Province, 071000, China
}

Keywords: knowledge management; college; library; human resource management; innovation

\begin{abstract}
College library, the center of the college literature information exchange and the extension of classroom teaching, plays an important role in school teaching and research. In the library management, the emphasis on the management mode with the center of the human resource management is not only the new thought and idea brought by the knowledge economy era for the library management, but also the inevitable development trend of the library management. In this paper, based on the author's learning and practical experience, we first interpreted the connotation of knowledge management and human resource management, and then analyzed the current situation and problems of human resource management in college library. Finally, the strategies of human resource management in college library based on the knowledge management were put forward.
\end{abstract}

\section{Introduction}

The emergence of knowledge economy and the rapid development of modern information technology make human society enter an economic era with the important contents of the possession, production, distribution and utilization of knowledge resource. Knowledge management has become the inevitable trend of the survival and development of various social organizations in this era. The timely introduction of knowledge management has become the inevitable choice of the development of the library, which is an important management department of organization, processing, treatment, transmission and utilization of social knowledge. Therefore, how to use the concepts of knowledge management, and deal well with the development and management work of library human resources in the new era have become an important subject of library science research.

\section{Connotation of Knowledge Management and Human Resource Management}

In regards to the definition of the connotation of knowledge management, many experts at home and abroad have put forward different views from different angles. For the college library, knowledge management is the comprehensive management of the university's knowledge resources through the modern information and technology in order to fully meet the changing users' needs of information and knowledge. Compared with the traditional information management of college library, knowledge management pays more attention to clarify the interrelationship of the information, grasp the interrelationship among the knowledge systems, and promote the transformation from the hidden knowledge to the explicit knowledge. Knowledge management includes information management and personnel management. In the general sense, knowledge management refers to the management of the "knowledge" object, which emphasizes that knowledge comes from data and information, and the data and information should be managed by the use of modern information technology. For the college library, the key to the implementation of knowledge management should be the improvement of the human resource management. Only if the level of human resource management is improved, can the knowledge management ability of the college library be strengthened, can the role of knowledge management be brought into full play, and can the benefits and efficiency of knowledge management be also revealed. 


\section{Current Situation and Problems of Human Resource Management in College Library}

\subsection{Lack of the new concepts of human resource development and management}

The personnel management in many college libraries basically still remains on the traditional personnel management, and is lack of the cognition of the new theory and importance of the human resource development and management. It is thought that the development of the library business only relies on the capital investment, and capital shortage is the real bottleneck of the development of the library. However, it is not aware that the real crisis and bottleneck in the development of the library is the lack of a high-quality and modern library workforce.

\subsection{Irrational human resource organizational structure}

Human resource organizational structure is an important organizational setup form of coordinating the human resource relationships inside the organizations and improving the quantity and quality of human resource. Under the traditional management system, the internal organizational structure of the college library is basically divided and set up according to the type of literature, the timing sequence of processing and utilization, and the administrative function. It is obvious that this kind of department arrangement mode is the reflection of literature-centered and collection-based management ideas, which embodies the library's workflow. However, it ignores the library's purpose of serving the readers, easily leads to the phenomena such as unclear responsibilities, organizational cross-duplication, single post responsibilities and inconvenient communication among some departments, and thus makes the comprehensive quality of the library staffs difficult to improve.

\subsection{Lack of systematic human resource development and management planning}

Human resource planning is an important basis for organizing various human resource management activities. In recent years, although the college library's human resource planning work has been gradually strengthened, there are still some problems. First, many college libraries are lack of the human resource planning. Their main features are arbitrary combination, mismatch between the learning and the application, mismatch between what they do and what they are good at, and lack of long-term plans and macro-control of personnel arrangement. Second, the formulation of human resource planning and the needs of the actual situation of college libraries are separated. Some local college libraries ignore their actual situation, and blindly copy the techniques and methods of human resource planning of the college library, which make human resources planning lack the proper environment, be divorced from the reality, have no operability, and not meet the actual needs of the development and management of their own library staff.

\subsection{Lack of relaxed and harmonious library interpersonal environment}

Active cultivation and creation of a distinctive, strong and harmonious library interpersonal environment is the foundation of college library human resource development and management, which is of great significance for stimulating the enthusiasm, initiative and creativity of the library staff, and promoting the realization of the goal of library human resource development and management. However, in practice, the construction of harmonious library interpersonal environment in many China's colleges only rests on the material carrier or on the blob, which is manifested in the lack of innovative library culture and values, weak library teamwork spirit, weak collective concept and overall awareness of library staff and low moral prestige and charisma of library's leaders. The disharmonious interpersonal environment of college library has greatly inhibited the initiative and creativity of library knowledge-based workers, which is the important reason for the lack of library talents, especially the innovative talents. 


\section{Strategies of College Library Human Resource Management Based on Knowledge Management}

\subsection{Reconstruct the human resource organizational structure}

The college library should break the traditional literature-based library organization arrangement mode, reconstruct the library organization with the standard of functions, make each module not only perform their functions but also be interconnected, and thus achieve the goal of complete functions, rational organization, coordinated operation, flexibility and high-efficiency. In the process of the specific practice, the first thing they should do is to merge the original interview and cataloging departments, and construct the literature and information resource department which is responsible for the literature information collection and processing work. The second thing they should do is to merge the original circulation, reading and particular collection departments, and construct literature service department which is responsible for the literature circulation and reading work. The third thing they should do is to merge the original journals, consulting, intelligence and retrieval departments, and construct information service department which is responsible for the development of various types of literature, retrieval, literature evaluation of scientific achievements and various kinds of network services, and provides the latest technology information and special information for the network database and users. The forth thing they should do is to merge the original technology department, electronic reading room, multimedia reading room and audio-visual reading room, and construct technology service department which is responsible for computer network, software and hardware maintenance, software development and online information processing. The fifth thing they should do is to merge the original counseling department into the office which is responsible for the tasks such as inter-library business exchange and academic exchange, and the organization of the library staff business training and freshmen entrance education.

\subsection{Establish the talent structure and configuration matching with library knowledge management strategy}

At present, when the college library conducts the specific formulation and implementation of human resource planning, the first thing they should do is to clarify the knowledge management development targets in each period, formulate the specific planning of library human resource which meets the knowledge management objectives in each period, and realize the integration of human resource planning and library knowledge management strategy according to the scale and actual situation of their own development. The second thing they should do is to establish and improve the human resource management system, clarify the special functional departments of human resource planning, and further improve the support platform for human resource planning, which can lay a solid foundation for effectively promoting the library's human resource planning work. The third thing they should do is to gradually establish the talent structure and configuration that match the library knowledge management strategy. The attention should be paid to the reasonable match between the age structure and level structure of the library staff.

\subsection{Further improve the humanized incentive mechanism}

An important task of library staff management is to enrich the existing incentives, and achieve the multi-dimensional development of the incentive system, meet people's various requirements which emerge with the improvement of the life quality, and thus stimulate the enthusiasm and creativity of the staff. In a word, the incentive system of human resource in college library should not only emphasizes the economy of human behavior, but also pays attention to the "people-oriented" and demand-satisfying multi-level and dynamic requirements.

\subsection{Create a relaxed and harmonious library interpersonal environment}

The creation of the relaxed and harmonious library interpersonal environment is the important content of library human resource management, and the crucial guarantee of enhancing the library organizational cohesion and vitality, and improving the efficiency and benefit of library 
organizational work. To this end, first, the library organizational culture should be innovated. The library organizational culture is the sum of the distinctive values, group consciousness, work style and way of thinking, which forms in the long practice, and is universally recognized and followed by the library members. It has strong integration, adaptation and orientation functions, can cultivate the sense of identity and belonging of the members so that an invisible resultant force is condensed between the organizations and members, makes the members change the old values and establish new values, imposes a flexible rational constraint on the members, and guides the behaviors and activities of the members via an adaptive culture. Second, the collective concepts and global awareness should be built up among the library staff. The pursuit of an organization is the best cohesion, overall resultant force and overall benefits. Therefore, it is necessary to cultivate the library staff to establish the collective consciousness and overall concepts, establish a spirit of collaboration, and build up a goal of joint endeavor. Finally, the interpersonal communication and coordination should be promoted among library staff. This is a necessary condition of the relaxed and harmonious library environment. The way of setting up suggestion box, having a heart-to-heart talk, holding the sodality and launching various collective activities can be used to enhance the communication and coordination between the organizations and the members, the members and the members, the organizations and the organizations.

\section{Summary}

In the new century of information, network and knowledge economy, the college library with high degree of modernization must take the human resource development as the fundamental driving force for the implementation of knowledge management of the library, clarify the situation, unify the understanding, increase the development strength of human resource, bring the individual and group advantages into full play, constantly enrich the human resource team, better meet the requirements of the new era, promote the implementation of library knowledge management, and boost the library cause to quickly, healthily and sustainably develop.

\section{References}

[1] KE Ping, ZHU Ming, YAN Na. Research review of foreign library management [J]. Journal of China Library, 2013, (05): 83-97.

[2] LIU Lili. Research on library human resource management from the perspective of knowledge management [J]. Library Journal, 2011, (05): 36-38.

[3] ZHU Ming, SUN Hongli. Strategies of college library human resource management based on the knowledge management [J]. Journal of Theory, 2009, (10): 94-95 + 100.

[4] CHE Jinshan. Ecological management of college library human resource [J]. Library Work and Reseach, 2008, (06):31-34.

[5] CUI Wenduan. Human resource management of college library innovation [J]. Modern Information, 2007, (12): 114-116.

[6] XU Chongrong. Current situation and strategy of library human resource management [J]. Chinese Journal of the Chengdu Municipal Party College (Philosophy and Social Sciences), 2006, (06): 66-67.

[7] LIU Chuanhe, TIAN Cai. Library human resource management under the guidance of knowledge management [J]. Library Forum, 2006, (01): 130-132. 